Jurnal Sulolipu : Media Komunikasi Sivitas Akademika dan Masyarakat

Vol. 19 No. 12019

e-issn : 2622-6960, p-issn : 0854-624X

\title{
KONDISI SANITASI KOLAM RENANG JE'NE TALLASA SILEO DESA PARAIKATTE KECAMATAN BAJENG KABUPATEN GOWA Widiyanti ${ }^{1}$, Andi Ruhban ${ }^{2}$ \\ 1,2Jurusan Kesehatan Lingkungan Politeknik Kesehatan Makassar \\ widiyanti809@gmail.com
}

\begin{abstract}
The swimming pool is a public place that should get supervision and attention to sanitation because it has potential as a place of disease transmission, environmental pollution, or other health problems. The purpose of this study is to determine the condition of sanitation Swimming Pool Je'ne tallasa Sileo Paraikatte Village District Bajeng Gowa District. The type of research used is observational with a descriptive approach that will describe the condition of swimming pool sanitation Je'ne tallasa Siloe. From the results of the research pool Je'ne tallasa Sileo for the overall variables obtained $89 \%$ results. The variables for environmental health requirements obtained $74 \%$ result, room/room health requirements $88 \%$ and sanitary facilities $76 \%$ of the third variables have met the standards but for the employee, variable get $0 \%$ and the water quality of this $9 \%$ pool means the results do not meet the standard. The conclusion is the swimming pool Je'ne tallasa Sileo Paraikatte Village Bajeng District Gowa regency was not fit healthy according to Permenkes 32 the Year 2017. A suggestion of pool manager should pay attention to the condition of sanitation, do bacteriological examination periodically and further research about the influence of visitor behavior of pond pool quality.
\end{abstract}

Keywords: Swimming Pool Sanitation

\section{ABSTRAK}

Kolam renang merupakan tempat umum yang harus mendapatkan pengawasan dan perhatian sanitasi, karena memiliki potensi sebagai tempat terjadinya penularan penyakit, pencemaran lingkungan, atau gangguan kesehatan lainnya. Tujuan penelitian ini adalah untuk mengetahui kondisi sanitasi Kolam Renang Je'ne tallasa Sileo Desa Paraikatte Kecamatan Bajeng Kabupaten Gowa. Jenis penelitian yang digunakan bersifat observasional dengan pendekatan secara deskriptif yang akan memberikan gambaran tentang kondisi sanitasi kolam renang Je'ne tallasa Siloe. Dari hasil penelitian kolam renang Je'ne tallasa Sileo untuk keseluruhan variabel diperoleh hasil $89 \%$. Adapun variabel untuk persyaratan kesehatan lingkungan memperoleh hasil $74 \%$, persyaratan kesehatan kamar/ruang $88 \%$ dan fasilitas sanitasi $76 \%$ dari variabel ketiga tersebut telah memenuhi standar akan tetapi untuk variabel karyawan memperoleh $0 \%$ dan kualitas air kolam $9 \%$ ini berarti hasil tersebut tidak memenuhi standar. Kesimpulan penelitian adalah kolam renang Je'ne tallasa sileo Desa Paraiksatte Kecamatan Bajeng Kabupaten Gowa tidak laik sehat menurut Permenkes 32 Tahun 2017. Saran sebaiknya pengelola kolam renang memperhatikan kondisi sanitasi, melakukan pemeriksaan bakteriologis secara berkala dan bagi peneliti selanjutnya meneliti lebih lanjut mengenai pengaruh perilaku pengunjung akan kualitas kolam renang.

\section{Kata Kunci : Sanitasi Kolam Renang}

\section{PENDAHULUAN}

Kolam renang tanpa adanya pengawasan sanitasi akan memungkinkan memberi dampak bagi kesehatan, baik pengunjung maupun pengelola dari suatu kolam renang. gangguan kesehatan yang biasa timbul antara lain gangguan penyakit kulit, gangguan penyakit mata, dan kemungkinan besar bisa menyebabkan gangguan penyakit yang berhubungan dengan perut (gastroenteritis) seperti: diare dan colera.

Pengawasan higiene yang teratur harus dilakukan terus menerus pada kolam renang, dan pengelola juga harus selalu memperhatikan aspek sanitasi pada kondisi lingkungan kolam renang. Antara lain aspek yang perlu diperhatikan yaitu: persyaratan kesehatan lingkungan dan bangunan, persyaratan kesehatan kamar/ruang, persyaratan kesehatan fasilitas sanitasi, pengelolaan sampah dan kualitas air kolam renang dan air permandian umum (Erlani, dkk 2014).

Dari penelitian Sri Wulandari (2015) bahwa kondisi sanitasi pada kolam renang wisata Bissua bangunan tidak memenuhi syarat sebesar $66.07 \%$, untuk fasilitas sanitasi hasil penilaian tidak memenuhi syarat $44.7 \%$, dan kualitas air kolam hasilnya tidak memenuhi syarat $50 \%$. Hasil penelitian Renita Agus (2017) hasil observasi dan pemeriksaan yang dilakukan di kolam renang Lasharan didapatkan hasil sanitasi memenuhi syarat dengan skor $71,89 \%$. Dari hasil penelitian Hatira (2016) hasil pemeriksaan yang dilakukan di kolam renang Eremerasa Bantaeng tidak memenuhi syarat karena persyaratan kesehatan lingkungan dan bangunan skor yang didapatkan kurang dari $70 \%$.

\section{METODE PENELITIAN}

\section{Lokasi Penelitian}

Lokasi untuk penelitian ini dilakukan di kolam renang Je'ne tallasa sileo Desa Paraikatte Kecamatan Bajeng Kabupaten Gowa.

\section{Variable Penelitian}

Variabel bebas dalam penelitian ini adalah lingkungan dan bangunan, kamar/ruang, fasilitas sanitasi, karyawan, dan kualitas air kolam renang. Variable terikat pada penelitan 
Jurnal Sulolipu : Media Komunikasi Sivitas Akademika dan Masyarakat

Vol. 19 No.12019

e-issn : 2622-6960, p-issn : 0854-624X

ini adalah Kondisi sanitasi kolam renang Je'ne tallasa Sileo.

\section{Definisi Operasional}

a. Kondisi sanitasi kolam renang yang dimaksud dalam penelitian ini adalah lokasi, lingkungan dan kontruksi bangunan pada kolam renang Je'ne tallasa sileo Desa Paraikatte Kecamatan Bajeng Kabupaten Gowa.

b. Kamar/ruang yang dimaksud dalam penelitian ini adalah kamar mandi dan ruang ganti pakaian pada kolam renang Je'ne tallasa sileo Desa Paraikatte Kecamatan Bajeng Kabupaten Gowa.

c. Fasilitas sanitasi yang dimaksud dalam penelitian ini adalah penyedian air, pancuran bilas, tempat sampah, tempat penampungan sampah sementara dan toilet umum pada kolam renang Je'ne tallasa sileo Desa Paraikatte Kecamatan Bajeng Kabupaten Gowa.

d. Karyawan yang dimaksud dalam penelitian ini adalah orang yang bekerja di kolam renang.

e. Kualitas air kolam renang yang dimaksud dalam penelitian ini adalah keadaan fisik(bau,kekeruhan,benda terapung) kimia(pH,sisa khlor) dan bakteriologi (E.coli) pada kolam renang Je'ne tallasa sileo Desa Paraikatte Kecamatan Bajeng Kabupaten Gowa.

\section{Kriteria Objektif}

a. Kondisi lingkungan dan bangunan kolam renang dikatakan memenuhi syarat apabila sesuai dengan standar variabel upaya Panduan Praktek Lapangan Sanitasi Tempat-tempat Umum yaitu $\geq 70$ $\%$ dan dikatakan tidak laik sehat apabila $<70 \%$.

b. Kesehatan kamar/ruang dikatakan laik sehat apabila sesuai dengan standar variabel upaya Panduan Praktek Lapangan Sanitasi Tempat-tempat Umum yaitu $\geq 60 \%$ dan tidak laik sehat apabila $<60 \%$.

c. Fasilitas sanitasi kolam renang dikatakan laik sehat apabila sesuai dengan standar variabel upaya Panduan Praktek Lapangan Sanitasi Tempat-tempat Umum yaitu $\geq 75 \%$ dan tidak laik sehat apabila $<75 \%$.

d. Kesehatan karyawan dikatakan laik sehat apabila sesuai dengan standar variabel upaya Panduan Praktek Lapangan

Sanitasi Tempat-tempat Umum yaitu $\geq$ $60 \%$ dan tidak laik sehat apabila < $60 \%$.

e. Kualitas air kolam renang dikatakan laik sehat apabila sesuai dengan standar variabel upaya Panduan Praktek Lapangan Sanitasi Tempat-tempat Umum yaitu $\geq 70 \%$ dan tidak laik sehat apabila $<70 \%$.

\section{Sampel}

Sampel dalam penelitian ini adalah kondisi sanitasi lingkungan dan bangunan, kamar/ruang karyawan dan air kolam renang Je'ne tallasa sileo Desa Paraikatte Kecamatan Bajeng Kabupaten Gowa. Pada sampel dan penelitian ini adalah kolam renang dewasa dan kolam renang anak-anak dengan waktu pengambilan sampel yaitu pagi dan sore jadi jumlah keselurahan sampel adalah 12 untuk pemeriksaan Kimia(pH,Sisa chlor) dan Biologi(E.coli).

\section{TEKNIK PENGAMBILAN DATA}

\section{Data Primer}

Data primer diperoleh melalui observasi langsung ke lapangan dan hasil pemeriksaan air kolam renang di laboratorium.

\section{Data Sekunder}

Data sekunder diperoleh dari lembaga instansi terkait sebagai literature seperti jurnal, $\mathrm{KTI}$, dan dari buku-buku referensi yang berkaitan dengan penelitian tersebut.

\section{Pengolahan Data dan Analisa Data}

Data diperoleh dari hasil observasi langsung dilapangan dan hasil pemeriksaan di laboratorium, dalam penelitian ini disajiakan dalam bentuk tabel dari data yang diperoleh dari hasil pemeriksaan di laboratorium.

\section{HASIL DAN PEMBAHASAN}

\section{Hasil Penelitian}

Penilaian persyaratan sanitasi kolam renang je'ne tallasa sileo desa paraikatte kecamatan bajeng kabupaten gowa. 
Jurnal Sulolipu : Media Komunikasi Sivitas Akademika dan Masyarakat

Vol. 19 No.12019

e-issn : 2622-6960, p-issn : 0854-624X

\begin{tabular}{|c|c|c|c|c|c|}
\hline $\begin{array}{l}\mathrm{N} \\
\mathrm{O}\end{array}$ & $\begin{array}{c}\text { Upaya } \\
\text { kesehatan } \\
\text { lingkunan }\end{array}$ & $\begin{array}{l}\text { Skor } \\
\text { Seben } \\
\text { arnya }\end{array}$ & $\begin{array}{l}\text { Skor } \\
\text { Penil } \\
\text { aian }\end{array}$ & $\begin{array}{c}\% \\
\mathrm{Pe} \\
\text { nila } \\
\text { ian }\end{array}$ & $\begin{array}{c}\text { \% } \\
\text { Min } \\
\text { ima } \\
\text { l }\end{array}$ \\
\hline 1 & $\begin{array}{c}\text { Persyarata } \\
n \\
\text { Kesehatan } \\
\text { Lingkungan } \\
\text { dan } \\
\text { Bangunan }\end{array}$ & 131 & 97 & $\begin{array}{l}74 \\
\%\end{array}$ & $\begin{array}{l}70 \\
\%\end{array}$ \\
\hline II & $\begin{array}{c}\text { Persyarata } \\
n \\
\text { Kesehatan } \\
\text { Kamar dan } \\
\text { Ruang }\end{array}$ & 68 & 60 & $\begin{array}{l}88 \\
\%\end{array}$ & $\begin{array}{l}60 \\
\%\end{array}$ \\
\hline III & $\begin{array}{c}\text { Persyarata } \\
n \\
\text { Kesehatan } \\
\text { Fasilitas } \\
\text { Sanitasi }\end{array}$ & 287 & 219 & $\begin{array}{l}76 \\
\%\end{array}$ & $\begin{array}{l}75 \\
\%\end{array}$ \\
\hline I & Karyawan & 0 & 0 & $0 \%$ & $\begin{array}{l}60 \\
\%\end{array}$ \\
\hline $\mathrm{V}$ & $\begin{array}{c}\text { Kualitas Air } \\
\text { Kolam } \\
\text { Renang }\end{array}$ & 9 & 70 & $9 \%$ & $\begin{array}{l}70 \\
\%\end{array}$ \\
\hline & Jumlah & 497 & 446 & $\begin{array}{l}89 \\
\%\end{array}$ & $\begin{array}{l}65 \\
\%\end{array}$ \\
\hline
\end{tabular}

2. Pembahasan

a. Persyaratan kesehatan lingkungan dan bangunan

Berdasarkan hasil observasi yang dilakukan pada lokasi kolam renang Je'ne tallasa Sileo Desa Paraikatte Kecamatan Bajeng Kabupaten Gowa pada hari Selasa tanggal 01 Mei 2018, pada penilaian untuk lokasi kolam renang telah memenuhi syarat karena terhindar dari pencemaran kimia, tidak terletak di daerah banjir. Kolam renang ini dapat dikases oleh masyarakat dengan menggunakan kendaraan umum. Selain itu tidak ditemukan faktor-faktor pencemaran fisika yang dapat mencemari lokosi tersebut. Dimana pencemaran fisik 
Jurnal Sulolipu : Media Komunikasi Sivitas Akademika dan Masyarakat

Vol. 19 No.12019

e-issn : 2622-6960, p-issn : 0854-624X

pencegahan masuknya serangga, area kolam renang, volume air kolam renang, konstruksi kolam dan bak cuci kaki.

Berdasarkan hasil observasi yang telah dilakukan penyediaan air kolam renang cukup untuk pengunjung yang berenang dikolam renang ini. Terdapat 3 kolam renang yang terdiri dari 2 kolam untuk anak-anak dan satu kolam untuk orang dewasa. Selain itu terdapat juga pancuran bilas yang dapat digunakan oleh pengunjung hanya saja belum disediakan sabun cair yang dapat digunakan untuk pengunjung setelah mandi dikolam.

Menurut peraturan PERMENKES No. 061/MENKES/Per/l/1991, jumlah air didalam kolam mencukupi, sistem penyediaan air kolam dilakukan secara saniter yang terlindung dari bahaya kontaminasi. Sedangkan untuk pancuran bilas harus bersih dan tidak berbau, air mengalir lancar dan continue, lantai kedap air dan tidak licin serta harus tersedia pancuran bilas minimal 1 pancuran untuk 40 perenang, pancuran bilas untuk pria harus terpisah dari pancuran bilas wanita, pada ruang pancuran bilas harus tersedia sabun cair dan lantai dari ruangan pancuran bilas harus terbuat dari bahan yang tahan dan rapat air.

Kondisi fisik untuk variabel upaya yang dinilai pada toilet untuk umum di kolam renang Je'ne tallasa sileo bisa dikatakan bersih dan tidak berbau karena adanya petugas kebersihan (cleaning servis) yang setiap waktu datang melihat dan membersihkan. Konstruksi toilet yang ada di kolam renang Je'ne tallasa Sileo terbuat dari bahan kedap air, tidak licin, lantai miring ke arah saluran pembuangan serta toilet terpisah antara toilet pria dan wanita begitu pula dengan toilet karyawan terpisah anatara pengunjung.

Menurut Suparlan 2012 menyatakan bahwa setiap 40 wanita disediakan 1 toilet, dan setiap 60 pria disediakan 1 toilet dan 1 urinoir, dalam ruangan toilet harus disediakan satu tempat cuci tangan (washing fasility) untuk setiap 40 perenang wanita maupun pria, ruangan toilet harus berventilasi yang baik, mempunyai penerangan yang baik dan konstruksi lantai sama dengan tempat berpakain.
Berdasarkan hasil pengamatan yang telah dilakukan adalah dimana tempat sampah selalu dibersihkan sesuai dengan yang telah dipersyaratkan oleh PERMENKES No. 061/MENKES/Per/l/1991, dan juga tempat sampah yang terbuat dari bahan yang kuat, ringan, tahan karat, kedap air, permukaan bagian dalam halus dan rata, selain itu juga mempunyai tutup yang mudah dibuka/ditutup tanpa mengotori tangan. Jumlah dan volume tempat sampah sesuai dengan produksi sampah perhari sehingga para pengunjung kolam renang Je'ne tallasa sileo dapat membuang sampah di tempat sampah yang telah disediakan oleh pihak pengengelolah kolam renang sehingga tidak mencemari lingkungan dan tidak mengurangi nilai estetika lingkungan disekitar kolam renang tersebut, pengadaan tempat sampah yang ada di sekitar kolam renang cukup memadai dan sampah dari tiap ruang mudah di angkut/dikosongkan tiap hari.

Tempat penampungan sampah sementara yang ada di kolam renang Je'ne tallasa Sileo tidak permanen, mudah dijangkau oleh kendaraan pengangkut sampah, frekuensi pengosongan/pengangkutan sampah minimal $3 \times 24$ jam sehingga tidak menjadi tempat perindukan serangga dan binatang penganggu yang lainnya.

Pada area kolam renang Je'ne tallasa Sileo terdapat suatu pemisahan yang jelas antara kolam renang dewasa dan kolam renang anak-anak sehingga tidak menyebabkan kecelakaan yang tidak di inginkan. Volume air kolam renang selalu terisi penuh dengan air dan jumlah perenang maksimum sebanding dengan luas permukaan air kolam renang.

d. Karyawan

Karyawan yang dimaksud di sini adalah petugas yang ada di kolam renang Je'ne tallasa sileo tidak memiliki surat keterangan sehat, kondisi kesehatan karyawan yang diterima masuk di Je'ne tallasa hanya dilihat secara fisik. Surat keterangan sehat sangat penting untuk setiap karyawan agar karyawan yang bekerja di Je'ne tallasa tidak memiliki riwayat penyakit apapun terutama penyakit yang menular, karena dapat membahayakan kondisi kesehatan 
Jurnal Sulolipu : Media Komunikasi Sivitas Akademika dan Masyarakat

Vol. 19 No.12019

e-issn : 2622-6960, p-issn : 0854-624X

pengunjung lainnya. Sehingga surat keterangan sehat dari semua pekerja dapat mejamin kesehatan setiap pekerja di kolam renang Je'ne tallasa sileo Desa Paraikatte Kecamatan Bajeng Kabupaten Gowa.

e. Kualitas air kolam renang

Air merupakan kebutuhan pokok pada berbagai aktivitas manusia. Selain untuk memenuhi kebutuhan sehari-hari, seperti memasak, mencuci, mandi, dan sanitasi, air juga dibutuhkan dalam jumlah besar untuk memenuhi kebutuhan pada aktivitas ekonomi dan sosial, seperti industri, rumah sakit, perhotelan, perdagangan, perkantoran, dan pendidikan/sekolah (Suprihatin,dkk 2013). Berdasarkan hasil penelitian yang telah dilakukan untuk kualitas air kolam renang mendapatkan hasil yang tidak memenuhi syarat karena tidak sesuai dengan Permenkes Nomor 32 Tahun 2017. Adapun hal-hal yang diperiksa yaitu dari parameter fisik untuk benda terapung, kejernihan dan bau dimana di air kolam renang je'ne tallasa sileo airnya berbau disebabkan karena jumlah kaporit yang berlebihan sehingga air berbau kaporit, pemberian kaporit sebaiknya diperhatikan. Menurut Suparlan (2012) dan untuk kejernihan tidak jernih dikarenakan jumlah pengunjung yang sangat padat sehingga menyebabkan air menjadi keruh.

Parameter Kimia (pH) dimana parameter tersebut memperoleh hasil untuk kolam renang anak-anak yang sebelum digunakan mendapatkan nilai sebesar 6,56 dan kolam renang yang sesudah digunakan mendapatkan nilai sebesar 6,20 sedangkan kolam renang dewasa yang sebelum digunakan mendapatkan nilai sebesar 6,02 dan kolam renang yang sesudah di gunakan mendapatkan nilai 6,15. Hal ini tersebut dikatakan tidak memenuhi standar sesuai dengan Permenkes Nomor 32 Tahun 2017 Untuk parameter pemeriksaan $\mathrm{pH}$ yaitu sebesar $7-7,8$. Apabila $\mathrm{pH}$ berlebihan maka akan menyebabkan korosifitas pada pipa-pipa air yang terbuat dari logam dan mengakibatkan beberapa senyawa kimia berubah menjadi racun yang dapat menganggu kesehatan manusia.

Menurut Permenkes Nomor 32 Tahun 2017 standar baku mutu untuk kolam renang adalah 1-1,5. Ini berarti sisa chlor air kolam renang tidak memenuhi syarat. Apabila sisa chlor terlalu tinggi dapat mengakibatkan sakit mata pada perenang. Klorinasi merupakan salah satu upaya desinfeksi air dengan maksud untuk membunuh bakteri pathogen yang terdapat dalam air, dan efektif tidaknya upaya ini tergantung pada sisa chlor bebas yang terdapat pada air kolam renang maupun lama pemakain kaporit sehingga kadar chlor yang dikandungnya habis terpakai dalam mengamankan air dalam pencemaran bakteri. Macam dan jumlah sisa chlor yang perlukan tergantung pada tujuan pengolahan air, bila tujuan desinfeksi maka suhu, $\mathrm{pH}$, daya ikat chlor dan mikroorganisme merupakan faktor yang dipertimbangkan.

Parameter bakteriologis (E.coli) berdasarkan hasil pemeriksaan yang di lakukan pada hari selasa tanggal 01 Mei 2018 di Laboratorium Poltekkes Makassar Jurusan Kesehatan Lingkungan untuk kualitas bakteriologis (E.coli) pada kolam renang Je'ne tallasa sileo Desa Paraikatte Kecamatan Bajeng Kabupaten Gowa didapatkan hasil 0 untuk kolam renang anak-anak dan dewasa yang sebelum digunakan dan untuk kolam renang anakanak yang sesudah digunakan mendapatkan hasil 5 per $100 \mathrm{ml}$ air dan kolam renang dewasa yang sesudah digunakan mendapatkan hasil >2400 dalam $100 \mathrm{ml}$ air. Menurut Permenkes No 32 Tahun 2017 standar baku mutu kolam renang untuk parameter E.coli adalah $<1$. Hasil tersebut menunjukkan bahwa air kolam renang tidak memenuhi persyaratan.

Penelitian ini sejalan dengan penelitian yang telah dilakukan oleh (Lili Surianti,2005) hasil yang didapatkan tidak memenuhi syarat pemeriksaan kualitas air kolam renang Tirta Lontara Kodam VII/WIRABUANA, (Sri wulandari 2015) hasil yang didapatkan tidak memenuhi syarat kolam renang wisata Bissua di kabupaten Takalar.

Terjadinya peningkatan E.coli pada kolam renang Je'ne tallasa sileo diakibatkan oleh faktor pengotoran. Pengotoran ini disebabkan oleh banyaknya jumlah pengunjung yang datang dan kebiasaan perenang yang kurang baik saat berenang kebiasaan tersebut sangat 
Jurnal Sulolipu : Media Komunikasi Sivitas Akademika dan Masyarakat

Vol. 19 No.12019

e-issn : 2622-6960, p-issn : 0854-624X

berpengaruh untuk kebersihan kolam renang renang. Dimana kebiasaan tersebut antara lain adalah membuang ingus, meludah dalam kolam, memakai baju berwarna-warni dalam kolam dan juga banyaknya perenang yang sering membuang air kecil di dalam kolam.

\section{Kesimpulan}

Dari hasil penelitian yang telah dilakukan pada kolam renang Je'ne tallasa Sileo Desa Paraikatte Kecamatan Bajeng Kabupaten Gowa tidak laik sehat. Maka dapat disimpulkan sebagai berikut :

1. Kondisi kesehatan lingkungan dan bangunan kolam renang Je'ne tallasa Sileo memenuhi syarat dengan hasil yang didapatkan $74 \%$.

2. Kondisi kesehatan kamar/ruangan kolam renang Je'ne tallasa Sileo memenuhi syarat dengan hasil yang didapatkan $88 \%$.

3. Pada fasilitas sanitasi kolam renang Je'ne tallasa Sileo memenuhi syarat dengan hasil yang didapatkan $76 \%$.
4. Kondisi kesehatan karyawan (surat keterangan sehat) kolam renang Je'ne tallasa Sileo tidak memenuhi syarat.

5. Kualitas air kolam renang Je'ne tallasa Sileo tidak memenuhi syarat dengan hasil yang didapatkan $9 \%$.

\section{Saran:}

1. Sebaiknya pengelola kolam renang tetap memperhatikan kondisi sanitasi kolam renang agar kondisi sanitasi kolam renang tetap memenuhi syarat.

2. Kepada pihak pengelola kolam renang Je'ne tallasa Sileo Desa Paraikatte Kecamatan Bajeng Kabupaten Gowa melakukan pemeriksaan Bakteriologis secara berkala agar kualitas air kolam renang tetap terjaga.

\section{DAFTAR PUSTAKA}

Erlani, Dkk. 2017. Panduan Praktek Lapangan Sanitasi Tempat-tempat Umum. Makassar: Kementerian Kesehatan Republik Indonesia Politeknik Kesehatan Makassar Jurusan Kesehatan Lingkungan

Haderiah, Dkk. 2016. Panduan Praktikum Mikrobiologi Program Studi D-III. Makassar: Kementerian Kesehatan Republik Indonesia Politeknik Kesehatan Makassar Jurusan Kesehatan Lingkungan.

Hatira. 2016. Kondisi Sanitasi Kolam Renang Eremerasa Kabupaten Bantaeng. Makassar: Jurusan Kesehatan Lingkungan Politeknik kesehatan Makassar (KTI tidak dipublikasikan)

Juherah, Dkk. 2016. Buku Penuntun Praktek Kimia Lingkungan. Makassar: Kementerian Kesehatan Republik Indonesia Politeknik Kesehatan Makassar Jurusan Kesehatan Lingkungan.

Kristonimala. 2009. Sanitasi Kolam Renang. (online). https://kristonimala.wordpress.com. Diakses 23 Desember 2017.

Mundiatun dan Daryanto. 2015. Pengolahan Kesehatan Lingkungan. Yogyakarta : Gava Media.

Novan Esma Rozanto. 2015. Tinjauan Kondisi Sanitasi Lingkungan Kolam Renang, Kadar Sisa Chlor, Dan Keluhan Iritasi Mata Pada Perenang Di Kolam Renang Umum Kota Semaran: KTI Jurusan IImu Kesehatan Masyarakat Fakultas Keolahragaan Universitas Negeri, Semarang.http://lib.unness.ac.id> filerPDF.(diakses 01 januari 2018).

Renita Agus. 2017. Kondisi Sanitasi Kolam Renang Wisata Lasharan Kecamatan Alla Kabupaten Enrekang. Makassar: Jurusan Kesehatan Lingkungan Politeknik kesehatan Makassar (KTI tidak dipublikasikan).

Republik Indonesia. 1991. Permenkes No. 061 Tahun 1991 Tentang Persyaratan Kolam Renang dan Permandian Umum. Kementrian Kesehatan Republik Indonesia : Jakarta. 
Jurnal Sulolipu : Media Komunikasi Sivitas Akademika dan Masyarakat

Vol. 19 No.12019

e-issn : 2622-6960, p-issn : 0854-624X

Republik Indonesia. 2017 Nomor 32, Tentang Standar Baku Mutu Kesehatan Lingkungan Dan Persyaratan Kesehatan Air Untuk Keperluan Higiene Sanitasi, Kolam Renang,Solus Per Aqua, Dan Pemandian Umum.

Soekidjo Notoatmodjo. 2010. Metode Penelitian Kesehatan. Jakarta: Rineka Cipta.

Sri Rejeki. 2015. Sanitasi Hygiene dan K3. Bandung: Rekayasa Sains.

Sri Wulandari. 2015. Studi Kondisi Sanitasi Kolam Renang Wisata Bissua di Kabupate Takalar: Jurusan Kesehatan Lingkungan Politeknik Kesehatan Makassar (KTI tidak dipublikasikan).

Suparlan. 2012. Pengantar Pengawasan Hygiene-Sanitasi Tempat-tempat Umum-Wisata \& Usaha-usaha Untuk Umum. Surabaya: Dua tujuh. 